
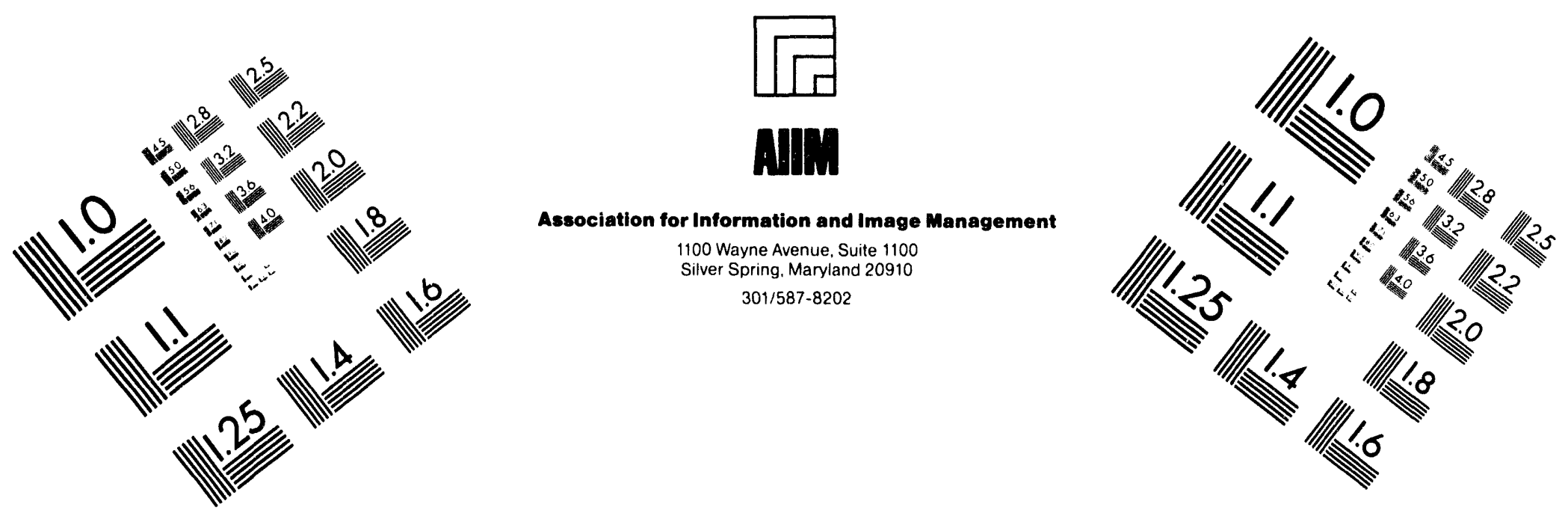

\title{
Centimeter
}

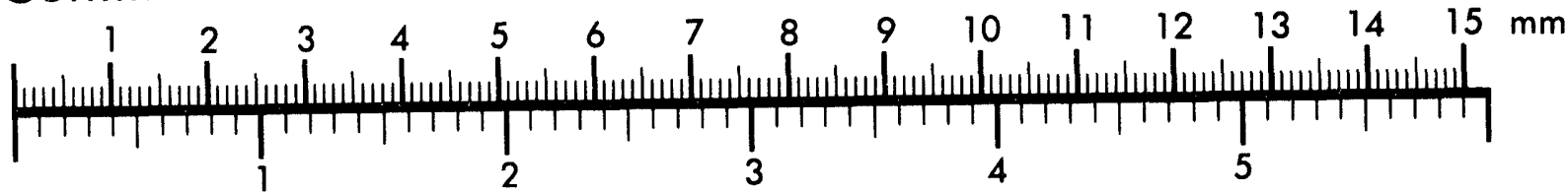
Inches

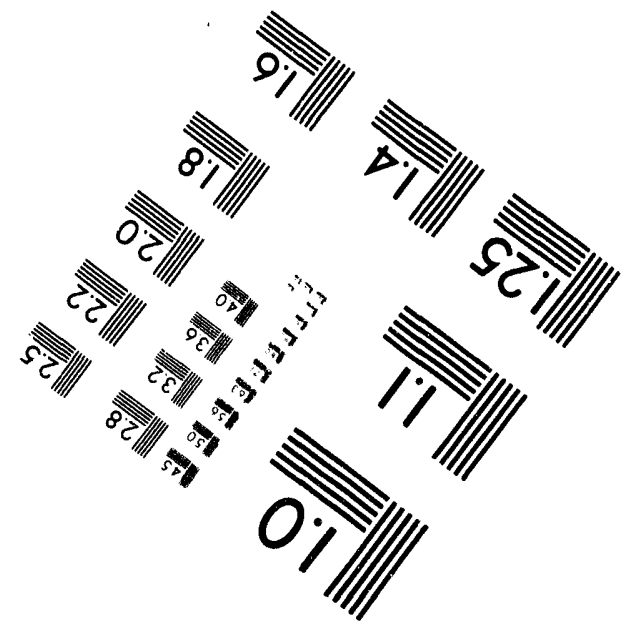

MANUFACTURED TO AIIM STANDARDS

BY APPLIED IMAGE, INC.

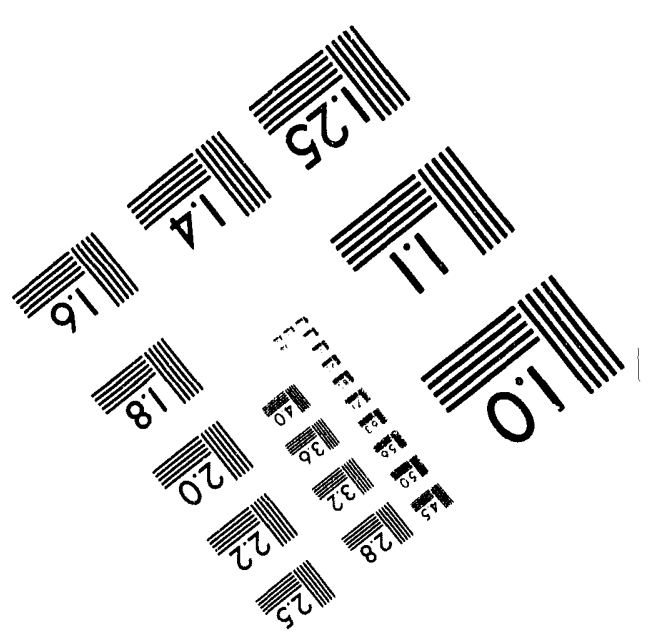



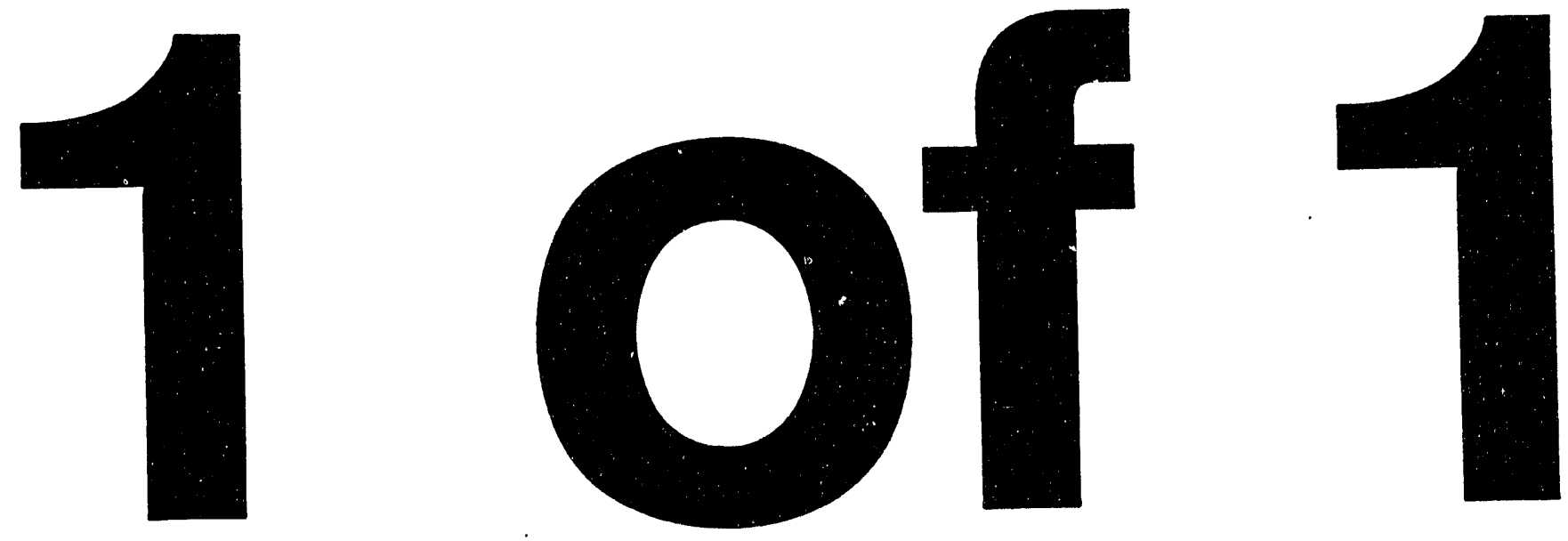
Distribution:

1. R. E. Burns

2. R. G. Ceier

3. $0 . \mathrm{F} \cdot \mathrm{Hill}$

4. E. R. Irish

5. R. B. Richards

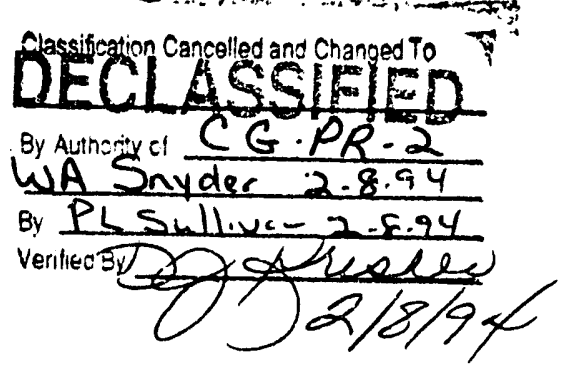

6. M. Siegler

T. R. J. SIoet

8. A. E. Smith

9. R. E. Tomlinson

10. M. T. Walling

11. 300 Files

12.-13. Extra

This document consists of

24 Pages, No. $\longrightarrow$ of

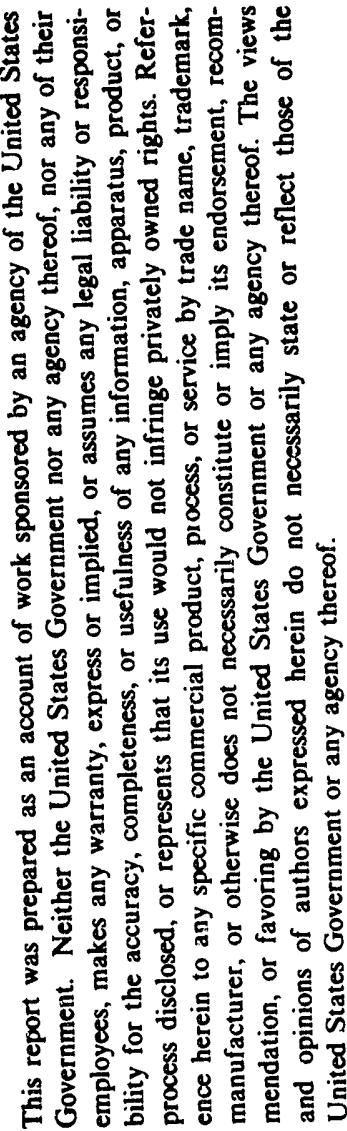

HOI SEATWORKS SUMMARY

RUN PX-13

By

M. Siegler and G. C. Oberg

August 24, 1956

Hot Semiworks Unit

Separations Technology Section

ENG INEER ING DEPARTYENTI

HANFORD ATOMIC PRODUCTS OPERATION

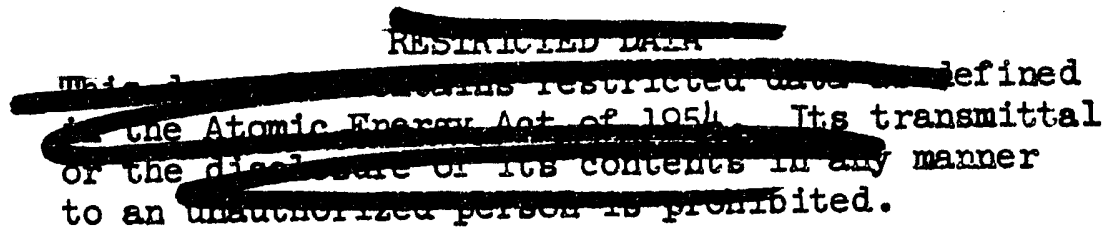

$\cdots$

\section{MASTER DECLASSIFIED}




\section{DECLASSIFIED}

$$
\text { a. } 2 \text {. }
$$

EH $45047 \mathrm{RD}$

\subsection{INERODUCITION}

During Run FX-12 acceptable HA Column decontamination was demonstrated; however, generally under unstable column operating conditions. The principal objectives of $\mathrm{PX}-13$ were:

a. To duplicate the bigh PX-12 decontamination factors under stable BA Column operating conditions.

b. To study the effects of fresh solvent, IO column CP carbonate vashed solvent, and IO Column Technical grade carbonate washed solvent on A Column decontamination factors.

c. To study the effect of Increasing the $\mathrm{BA}, \mathrm{EC}$, and IA uranium processing rates to 14 tons per day (plant equivalent).

d. To study the effect of an intermediate $2 A$ Column scrub on $U_{1}$ decontamination.

e. To study the effect of sulfamic acid addition to the HAF, HAS, IAF, and IAS and NaNOC amission from the HAF and IAF.

\subsection{STMMARY}

Changing from fresh solvent ( $30 \%$ TBP in shell E-2342) to normal Io Column carbonate washed recycled solvent, decreased the HA Column laboratory decontamination factors from approximately 2000 to $600-1000$. BA and IA Column laboratory decontamination factors (600-1000 and 60-180 respectively) remained essentially constant for recycled solvent contacted in the Io colum with either CP or Technical grade sodium carbonate. Intermediate scrub introduction to the $2 \mathrm{~A}$ Column resulted in $8.23 \%$ 2AW filutonium losses (based on $2 A F$ ) due to the short ( $8 \mathrm{ft})$.$2 A Column extraction section.$

Increasing the EA Column plant equivalent operating rate from 10 to 14 tons $\mathrm{U} /$ day permitted the scrub section to operate closer to its flooding amplitude. frequency product and improved the decontamination by a factor of approximately 2.

No significant plutonium loss can be attributed to the omission of sodium nitrite from the HAF and the addition of sulfamic acid to the HAF and HAS. However, high IAW plutonium losses (7-30 times the Purex Flowsheet HW \#3 value of $(0.2 \%)$ may quite possibly be attributed to the omission of sodium nitrite from the IAF and the addition of sulfamic acid to the IAF and IAS streams.

The principal solvent extraction data are sumarized in Table 2.1. More detalled results appear in Tables 5.1 to 5.3 and Figures 5.1 to 5.4 . 


\section{TABLE 2.1}

SOLVENT EXIRACTION SUMMARY DATA (I)

PRECYCLE(2)

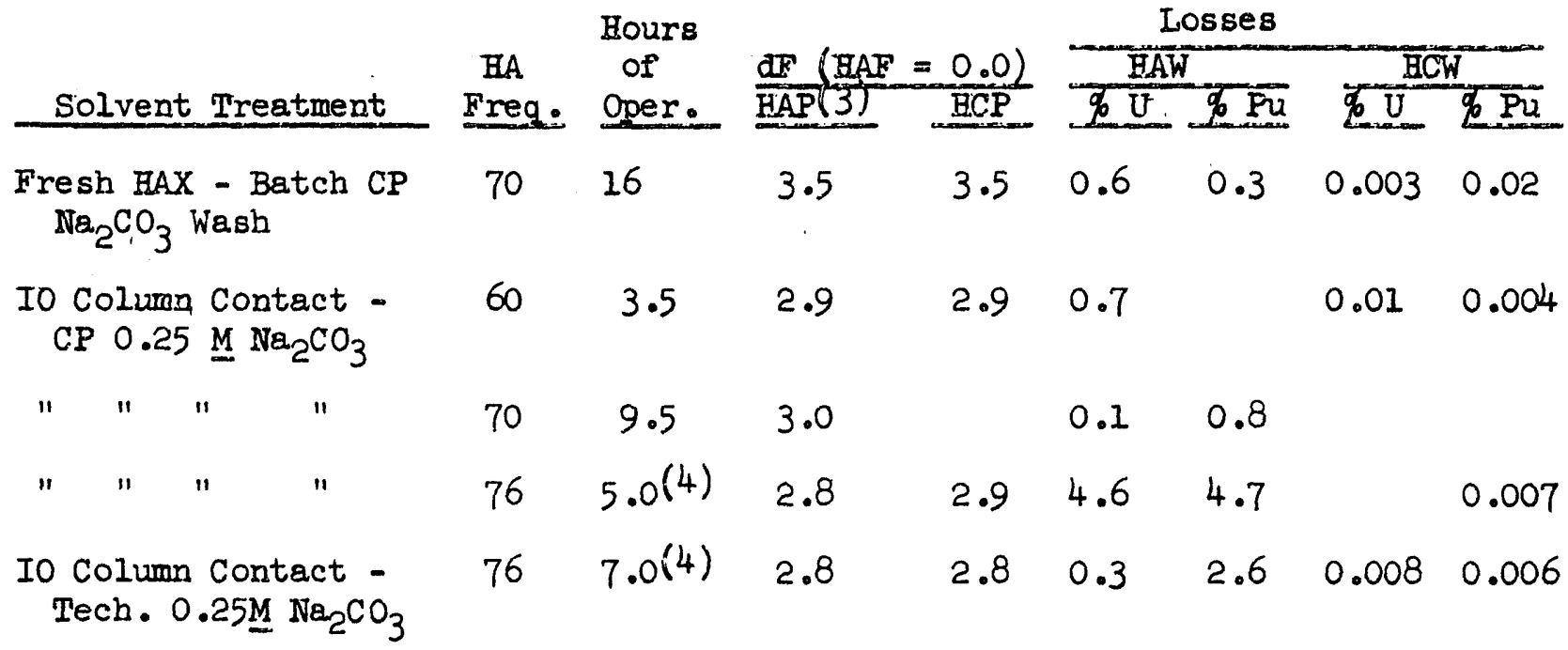

\section{PARTIIION CYCIE $(5)(6)$}

\begin{tabular}{|c|c|c|c|c|c|c|c|c|}
\hline \multirow[b]{2}{*}{ Solvent Treatment } & \multirow{2}{*}{$\begin{array}{l}\text { IA } \\
\text { Ereg. }\end{array}$} & \multirow{2}{*}{$\begin{array}{c}\text { Hours } \\
\text { of } \\
\text { Oper. }\end{array}$} & \multicolumn{4}{|c|}{$d F \quad(I A F=0.0)$} & \multicolumn{2}{|c|}{ IAW Losses } \\
\hline & & & $\operatorname{IAP}(7)$ & IBP & IBU & ICU & $9 \mathrm{U}$ & of $\mathrm{Pu}$ \\
\hline $\begin{array}{l}\text { IO Column Contact - } \\
\text { CP } 0.25 \mathrm{M} \mathrm{Na}_{2} \mathrm{CO}_{3}\end{array}$ & 60.72 & 19 & $1.9-2.2$ & 1.9 & 2.4 & 2.8 & 0.001 & $1.3 \cdot 3 \cdot 5$ \\
\hline$"$ & $62-66$ & 10.5 & $1.3-2.0$ & $2 \cdot 3$ & 2.6 & 2.7 & 0.002 & 1.5 \\
\hline $\begin{array}{l}\text { IO Col. Contact - } \\
\text { Tech. } 0.25 \mathrm{M} \mathrm{Na}_{2} \mathrm{CO}_{3}\end{array}$ & 66 & 5.0. & 1.9 & & & & 0.0006 & 6.5 \\
\hline " $\quad " \quad "$ & $70-80^{(8)}$ & $6.0(9)$ & 2.2 & 2.0 & 2.3 & & 0.05 & 10.1 \\
\hline
\end{tabular}




\section{DECLASSIFIED}

$$
-4
$$

BW 45047 RD

TABLE 2.1 (Continued)

FITAL PLUTORTIM CYCLE(10)

\begin{tabular}{|c|c|c|c|c|c|}
\hline & $\begin{array}{l}\text { Hours } \\
\text { of }\end{array}$ & $\frac{d F \text { (IAF }}{d F}$ & $\frac{=0.0}{2 A P}$ & & $\begin{array}{l}2 A W^{(12)} \\
\text { o } \mathrm{Pu}\end{array}$ \\
\hline 2AIS (II) FlOW $($ BAF $=100)$ & Oper. & $2 A F$ & 2AP & $2 \mathrm{BP}$ & \\
\hline $\begin{array}{r}0.0 \\
5.0 \\
.7 .0\end{array}$ & $\begin{array}{l}28.5 \\
20.0 \\
16.5\end{array}$ & $\begin{array}{l}1.9 \\
2.0 \\
2.0\end{array}$ & $\begin{array}{l}3.9 \\
4.0 \\
4.1\end{array}$ & $\begin{array}{l}4.4-5.4 \\
5.3 \\
5.3\end{array}$ & $\begin{array}{l}0.2-1.2 \\
2.2-11.0 \\
12.6-23.0\end{array}$ \\
\hline
\end{tabular}

\section{Notes:}

1. Based on laboratory results.

2. BA (ex) total flow $=691$ gal. $/\left(\mathrm{hr}_{2}\right)($ sq.ft.) $)$ ( 14 tons of uranium per day plant equivalent.)

3. For 3.5 dF the HAP fission product distribution was $60-65 \%$ Zrisb and 35-40\% Ru. For 2.8-3.0 dF the HAP fission product distribution was $75-90 \% \mathrm{ZrNb}$ and $10-25 \% \mathrm{Ku}$.

4. Uncentrifuged HAF used during this portion of run. $\mathrm{HAF}$ temperature $=18^{\circ} \mathrm{C}$.

5. IA (ex) total flow $=691 \mathrm{gal} /\left(\mathrm{hr}_{\mathrm{p}}\right)(\mathrm{sq} . \mathrm{ft} \mathrm{t})$. ( 14 tons of uranium per day plant equivalent.) All partition cycle columns operated at 14 tons of uranium per day plant equivalent. IA Column amplitude $=1.2$ in. (ext. section) except as noted.

6. Average $\mathrm{BAF} / \mathrm{IAF} \mathrm{dF}=2.9$.

7. IAP fission product distribution $=80-90 \% \mathrm{ZrNb}$ and $10-20 \% \mathrm{Ru}$.

8. IA Column extraction section amplitude $=1.07-1 \mathrm{ach}$.

9. IA Column cyclic flooding during this entire portion.

10. $2 A$ (ex) total flow $=265 \mathrm{gal} . /(\mathrm{hr}).(\mathrm{sq} . \mathrm{ft}$.) for $0 \mathrm{ml} . / \mathrm{min}$. 2AIs flow. (10 tons of uranium per day plant equivalent.)

11. 2AIS = water. 2AIS introduced as an intermediate scrub stream.

12. 2AW losses are based on $2 A F$ plutonium concentration. 

$-5-$
$B W-45047 R D$

\section{TABLE 2.2}

\section{RUN' CHRONOLOGY}

\begin{tabular}{|c|c|c|}
\hline Date & Time & \\
\hline $1-11-56$ & & Charged 1248 -inch slugs. \\
\hline $\begin{array}{l}1-15-56 \\
\text { to } \\
1-18.56\end{array}$ & 0610 & Jacket removal and dissolution. \\
\hline $1-18-56$ & $\begin{array}{l}0715 \\
2350\end{array}$ & $\begin{array}{l}\mathrm{HA}-\mathrm{HC} \text { Column started at } 14 \mathrm{~T} / \mathrm{D} \text { with fresh } \mathrm{HAX} \text {. } \\
\text { Switched to Io Column } \mathrm{CP} \mathrm{Na}_{2} \mathrm{CO}_{3} \text { wasied } \mathrm{HAX} \text {. }\end{array}$ \\
\hline $1.19-56$ & 1440 & $\begin{array}{l}\text { Started using uncentrifuged HAF. } \\
\text { Switched to Io Column Technical Grade } \mathrm{Na}_{2} \mathrm{CO}_{3} \\
\text { washed } \mathrm{HAX} \text {. }\end{array}$ \\
\hline $1-20-56$ & 0240 & $\begin{array}{l}\text { Shut down HA-HC cycle. HAF temperature has been } \\
18^{\circ} \mathrm{C} \text { since } 1600 \text { 1-19-56. }\end{array}$ \\
\hline & 0640 & $\begin{array}{l}\text { IA Colume started }\left(\mathrm{a}=1.2^{\prime \prime}\right) \text { at } 14 \mathrm{~T} / \mathrm{D} \text { with IO Column } \\
\mathrm{CP} \mathrm{Na}_{2} \mathrm{CO}_{3} \text { washed } \mathrm{IAX} \text {. }\end{array}$ \\
\hline & 0910 & Started IBX, IBS, and IC Columns. \\
\hline & $0910-1400$ & IBS Column flooding out bottom. \\
\hline & $1235-1705$ & IA Column cyclic flooding. \\
\hline & 1420 & Started $2 A-2 B$ Columns. \\
\hline & 2320 & IA top DP cell increasing. \\
\hline $1-21-56$ & 0115 & $\begin{array}{l}\text { IA Column flooding in scrub section. Reduced IA } \\
\text { frequency to } 70 \text {. }\end{array}$ \\
\hline & 0330 & IA Column stable at frequency $=62$. \\
\hline & 0820 & Shut down IBX, IBS, and IC Columns. \\
\hline & 1205 & $\begin{array}{l}\text { Switched to Io Column Technical Grade } \mathrm{Na}_{2} \mathrm{CO}_{3} \text { washed } \\
\text { IAX and } 2 \mathrm{AX} \text {. }\end{array}$ \\
\hline
\end{tabular}

IAX and $2 A X$. 


\section{DECLASSIFIED}

ara

Date

Time

$1-21-56 \quad 1230$

1645

1735

1840

1905

1910

2045

2210

2250

$1-22-56 \quad 0200$

0640

1115

1500

$1-23-56 \quad 0740$
$H W-45047 R D$

TABIE 2.2 (Continued)

Started IBX, IBS, and IC Columns.

Reduced IA Column amplitude from $1.2 \mathrm{in}$. to $1.07 \mathrm{in}$.

IA Column flooding.

IRS Column flooding out bottom. Reduced IBS Column frequency to 40 .

Shut down IBX, IBS, and IC Columas.

Started 2AIS at $15 \mathrm{ml} . \mathrm{min}$.

Started IBX, IBS, and IC Columns.

IBS Column flooding. Reduced IRS frequency to 30 .

Shut down IA Column.

Shut down IBX, IBS, and IC Columns.

Started IBX, IBS, and IC Columss.

Shut down IBX, IBS, and IC Columns.

Increased $2 A I S$ to $21 \mathrm{ml} . / \mathrm{min}$.

Shut down $2 A-2 B$ cycle. 


\subsection{EQUIPMENT AND FLOWSHEETT}

No equipment changes were made between runs PX-10 and PX-13. The column dimensions and operating conditions are given in Table 3.1 for $14 \mathrm{~T} / \mathrm{D}$ rates in the Precycle and Partition cycle colums and $10 \mathrm{~T} / \mathrm{D}$ rates for the Second Plutonium cycle and Solvent Treatment columns. Due to the feed centrifuge fallure, the last 12 hours of the run was operated with uncentrifuged HAF.

Purex Flowsheet - HW \#3 was used with the following modifications:

(I) HAS and IAS $=3.0 \mathrm{M} \mathrm{HNO}_{3}-0.5 \% \mathrm{NH}_{2} \mathrm{SO}_{3} \mathrm{H}$.

(2) HAF and IAF $=1.35 \mathrm{MU}, 2.0 \mathrm{M} \mathrm{H} \mathrm{HrO}_{3}$ and $0.5 \% \mathrm{NH}_{2} \mathrm{SO}_{3} \mathrm{H}$.

(3) HA Column single scrub operation; HAF':HAS:HAIS $=100: 67: 0$ 。

(4) No $\mathrm{H}_{2} \mathrm{O}$ or $\mathrm{NaNO}_{2}$ was added to the $\mathrm{No}$. 1 waste concentrator.

(5) $\mathrm{NaNO}_{2}$ addition to the $2 \mathrm{AF}$ only.

(6) IOF: IOS:IOR $=100: 56: 44$.

(7) 2AIS flow $\left(\mathrm{H}_{2} \mathrm{O}\right)$ was 0 during the first portion of the run, 5.0 during second portion of $\mathrm{rum}$ and 7.0 during last portion of run. $($ HAF flow $=100)$.

Flow rates and composition of streams entering the columns are listed in Table 3.2. A schematic equipment flowsheet for the Hot Semiworks is shown as Figure 3.1 .

\section{DECLASSIFIED}


TABLE 3.1

COLUMIN OPERATING DATA

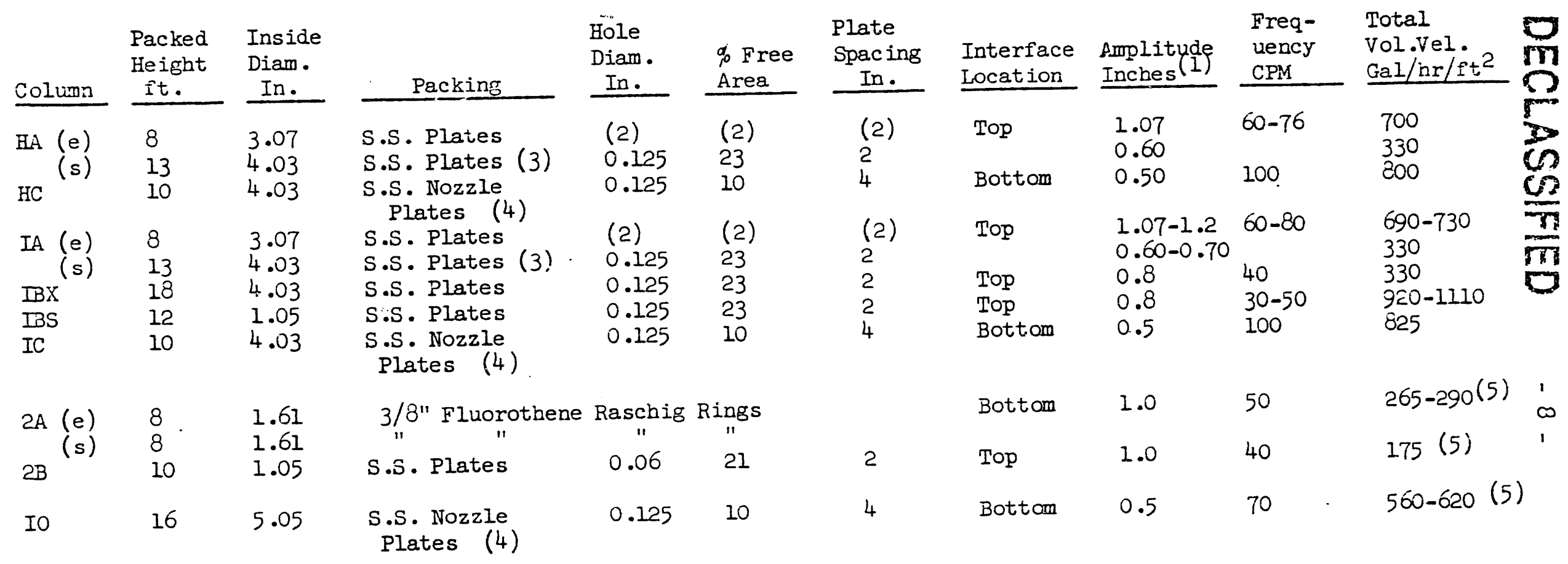

(1) Amplitudes are based on total cross sectional area of the columns. The Raschig Ring packing in the $2 A$ Column increases the actual column amplitude to approximately 1.5 inches.

(2) "Graded Cartridge", see Figure 3.2 (HW-43074 RD) for details of HA and IA cartridges.

(3) Anti-backmixing plate at feed tee (See HW-39517 RD for details of oonstruction).

(4) Nozzle depth $=0.035$ inches.

(5) $2 \mathrm{~A}, 2 \mathrm{~B}$, and Io Columns operated at $10 \mathrm{~T} / \mathrm{D}$. All other columns operated at $14 \mathrm{~T} / \mathrm{D}$. 
TABLE 3.2

FIOW RATES AND COMPOSITIONS

OF EMTER IMG STREAMS

\begin{tabular}{|c|c|c|c|}
\hline Stream & Composition, $G / L$ & $\begin{array}{l}\text { Elow } \\
\text { FX-13 }\end{array}$ & Min. \\
\hline \multirow{5}{*}{$\begin{array}{l}\text { HAF } \\
\text { HAIS } \\
\text { HAS } \\
\text { HAX } \\
\text { HCX } \\
\end{array}$} & $\mathrm{U}=337 ; \mathrm{HNO}_{3}=130 ; \mathrm{Pu}=0.07 ; \mathrm{NH}_{0} \mathrm{SO}_{3} \mathrm{H}=7.5$ & $435 *$ & \multirow{5}{*}{$\begin{array}{l}420 \\
140 \\
140 \\
1540 \\
2800 \\
\end{array}$} \\
\hline & & $0 *$ & \\
\hline & $\mathrm{HNO}_{3}=194 ; \mathrm{NH}_{2} \mathrm{SO}_{3} \mathrm{H}=5.5$ & $290^{*}$ & \\
\hline & $30 \%$ TRP $=70 \%$ shell E-2342 & 1540 & \\
\hline & $\mathrm{EMOO}_{3}=0.63$ & $2870 *$ & \\
\hline \multirow{8}{*}{$\begin{array}{l}\text { IAF } \\
\text { IAS } \\
\text { IAIS } \\
\text { IAX } \\
\text { IBS } \\
\text { IBX } \\
\text { IBXF } \\
\text { ICX } \\
\end{array}$} & $\mathrm{U}=330 ; \mathrm{HNO}_{3}=125 ; \mathrm{Pu}=0.077 ; \mathrm{MH}_{2} \mathrm{SO}_{3} \mathrm{H}=7.5$ & 440 & \multirow{8}{*}{$\begin{array}{l}420 \\
280 \\
0 \\
1540 \\
250 \\
126 \\
1920 \\
2800 \\
\end{array}$} \\
\hline & $\mathrm{HNO}_{3}=194 ; \mathrm{NH}_{2} \mathrm{SO}_{3} \mathrm{H}=5.5$ & $280 *$ & \\
\hline & & 0 & \\
\hline & $30 \%$ IBP - $70 \%$ shell E-2342 & 1580 & \\
\hline & $30 \%$ TRP - 70\% Shell E-2342 & 240 & \\
\hline & $\mathrm{MNO}_{3}=6.3 ; \mathrm{Fe}^{++}=1.7$ & $140 \pm 20 *$ & \\
\hline & $\mathrm{U}=76 ; \mathrm{HNO}_{3}=13 ; \mathrm{Pu}=0.018$ & 1700 & \\
\hline & $\mathrm{HNO}_{3}=0.63$ & $2900 *$ & \\
\hline \multirow{4}{*}{$\begin{array}{l}2 A F \\
2 A S(2) \\
2 A X \\
2 B X\end{array}$} & $\mathrm{HNO}_{3}=330 ; \mathrm{Pu}=0.06 ; \quad \mathrm{NaNO}_{2}=5.8$ & 168 & \multirow{4}{*}{$\begin{array}{l}172 \\
21.6 \\
43 \\
21.6 \\
\end{array}$} \\
\hline & $\mathrm{HNO}_{3}=30$ & 23 & \\
\hline & $30 \%$ TBP - $70 \%$ shell $\mathrm{E}-2342$ & 44 & \\
\hline & $\mathrm{ENO}_{3}=0.63$ & $23 *$ & \\
\hline \multirow{3}{*}{$\begin{array}{l}\text { IOF } \\
\text { IOR } \\
\text { IOS }\end{array}$} & $30 \%$ TEP - 70\% Shell E-2342 & $2400-3000$ & \multirow{3}{*}{$\begin{array}{l}2420 \\
700 \\
110 \\
\end{array}$} \\
\hline & $\mathrm{Na}_{2} \mathrm{CO}_{3}=26$ & ca. 1050 & \\
\hline & $\mathrm{Na}_{2} \mathrm{CO}_{3}=26$ & $1300 *$ & \\
\hline
\end{tabular}

* Calculated flrom tank depletion rates; others are by rotameter readings.

(1) $2 A, 2 B$, and IO Columns operated at $10 \mathrm{~T} / \mathrm{D}$ plant equivalent rates. AII other columns operated at $14 \mathrm{~T} / \mathrm{D}$.

(2) $2 A$ Column operated with $2 A I S\left(\mathrm{H}_{2} \mathrm{O}\right)$ during last two portionz of run. 2AIS rate was $15 \mathrm{ml} / \mathrm{min}$ for second portion and $21 \mathrm{ml} / \mathrm{min}$ for third portion of $2 A-2 B$ run. 


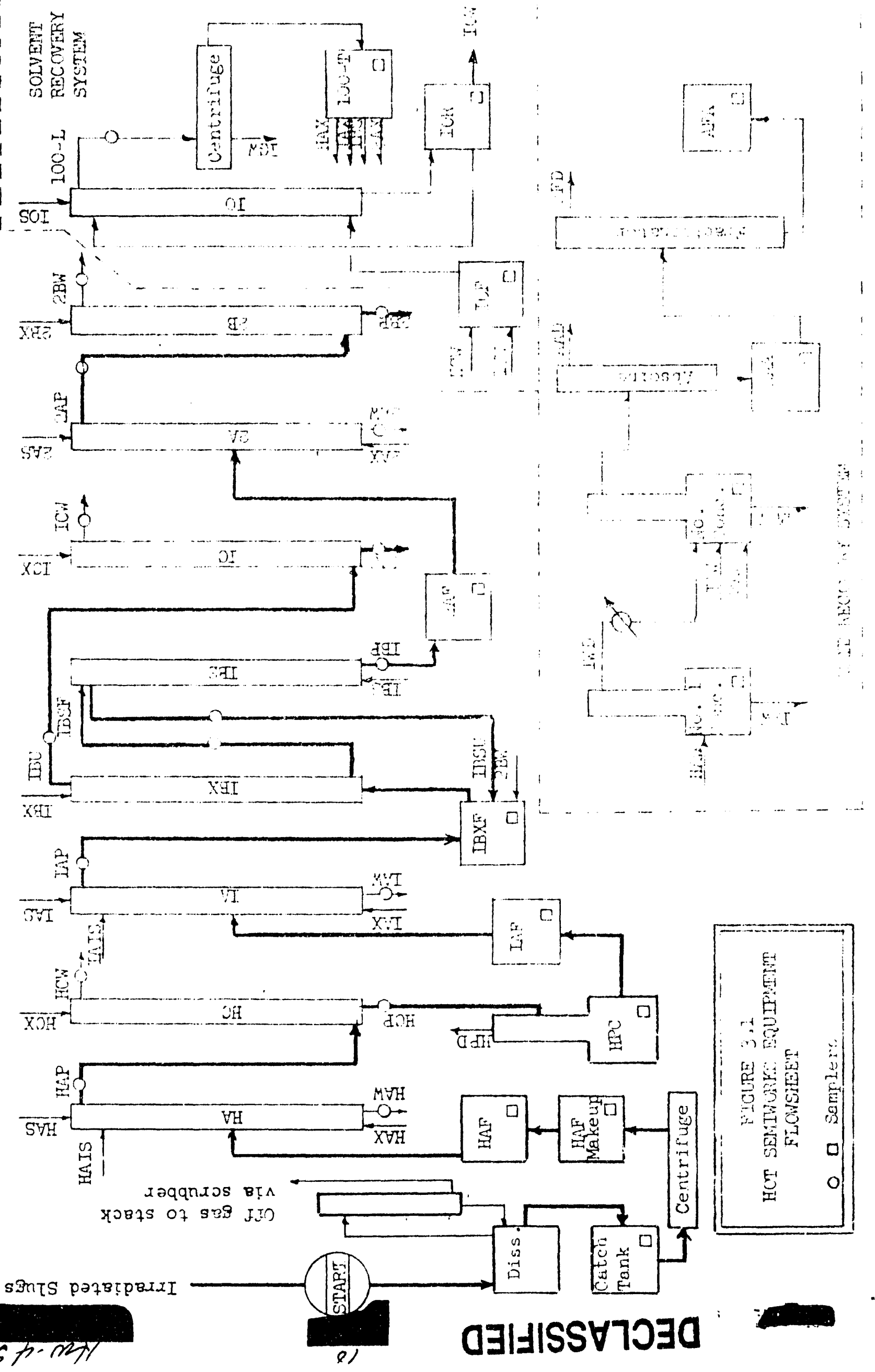




\subsection{FEED PREPARATION}

\subsection{SIug Charging}

For Run PXo.13, 985 pounds of uranium metal (246 MWD/T cooled 133 days at the time of dissolving) were added to an empty dissolver.

4.2 Jacket Removal

The slug jackets were removed by the standard procedure of boiling for three hours in a solution initially containing 600 pounds of 26 weight per cent $\mathrm{NaNO}_{3}$ and 164 pounds of 50 weight fer cent $\mathrm{NaOH}$. Operation was normal.

\subsection{Dissolution}

Data obtained during the dissolution are reported in Table 4.1 . A total of 875 pounds of uranium was dissolved in four downdraft cuts with an average acid consumption of approximately $2.75 \mathrm{mols}$ of $\mathrm{HNO}_{3}$ per mol of uranium dissolved. Operation was normal.

4.4 Centrifugation and Feed Adjustment

Tue to seal water dilution, cuts $I$ and 2 were concentrated prior to centrifugation. The first three cuts were conined after centrifugation and adjusted to HAF specifications by addition of nitric acid, sulfamic acid, and water. No $\mathrm{NaNO}_{2}$ addition was made. The feed was aigested for two hours at $70^{\circ} \mathrm{C}$. The fourth dissolver cut was not centrifuged due to mechanical failure of the centrifuge; otherwise feed preparation was the same as Cuts 1 and 2 . 
TABLE 4.1

DISSOLUTION DATA

\begin{tabular}{|c|c|c|c|c|}
\hline \multicolumn{5}{|c|}{ Cut Number } \\
\hline & 1 & 2 & 3 & 4 \\
\hline \multirow{2}{*}{$\begin{array}{l}\text { Source of acid } \\
\text { Initial acid concentration, } q_{0}(1)\end{array}$} & Fresh & Fresh & Fresh & Fresh \\
\hline & 48 & 48 & 48 & 48 \\
\hline \multirow{2}{*}{$\begin{array}{l}\text { Initial acla concentrat } \\
\text { Weight of } 100 \% \mathrm{HNO}_{3}, \mathrm{Lb} \text {. } \\
\text { Uranium charged, } \mathrm{Lb} \text {. }\end{array}$} & 237 & 237 & 237 & 153 \\
\hline & 985 & & & \\
\hline \multirow{5}{*}{$\begin{array}{l}\text { Reflux water addition, Lb. } \\
\text { Reflux addition duration, } \mathrm{Hr} \text {. } \\
\text { Air addition rate, SCFM } \\
\text { Time at boiling, Hr. } \\
\text { Final specific gravity (boiling) }\end{array}$} & 50 & 50 & 50 & 33 \\
\hline & 1 & 1 & 1 & 0.5 \\
\hline & 4.9 & 4.5 & 4.9 & 4.7 \\
\hline & 5.5 & 6.0 & 8.5 & 9.0 \\
\hline & 1.71 & 1.71 & 1.71 & 1.76 \\
\hline \multirow{2}{*}{$\begin{array}{l}\text { Final yapor temperature, }{ }^{\circ} \mathrm{C} \text {. } \\
\text { Uranium dissolved, } \mathrm{Lb} \text {. }\end{array}$} & $\ldots$ & -- & -- & -- \\
\hline & \multicolumn{2}{|c|}{454} & 231 & 191 \\
\hline \multirow{4}{*}{$\begin{array}{l}\text { Dissolver heel, } \mathrm{Lb} \text {. } \\
\text { Acid consumed (2) } \\
\text { Dissolver solution, } \mathrm{U} \underline{\mathrm{M}} \\
\text { Dissolver solution, } \mathrm{HNO}_{3} \mathrm{M}\end{array}$} & \multicolumn{2}{|c|}{532} & 300 & 109 \\
\hline & \multicolumn{2}{|c|}{2.85} & 2.80 & 2.50 \\
\hline & \multicolumn{2}{|c|}{2.6} & 2.3 & 2.8 \\
\hline & \multicolumn{2}{|c|}{2.8} & 2.5 & 1.7 \\
\hline
\end{tabular}

(1) Includes reflux water addition.

(2) Moles of $\mathrm{HNO}_{3}$ per mole of uranium dissolved. 


\subsection{SOLVENT EXIRACTION}

\subsection{Operation}

Prior to the start of Run PX-13 the solvent remaining in the columns was displaced and the solvent in the various solvent tanks was removed from the system. All columns and tanks were then emptied and the entire system was flushed with 5-10\% $\mathrm{BNO}_{3}$ to remove all high $\mathrm{MND} / \mathrm{T}$ material remaining from Run PX-10. Prior to column startup, all columns were filled to the normal interface level with cold aqueous streams. The startup procedure entailed simultaneous start of all cold and hot streams.

HA Column operation was divided into three main portions, each using a different type of HAX organic treatment, as indicated on Flgure 5.1. The first 15 hours of operation utilized fresh solvent as $\mathrm{HAX}$; the next 20 hours, $\mathrm{CP}$ $\mathrm{Na}_{2} \mathrm{CO}_{3}$ washed IOF and the last seven hours, Technical Grade $\mathrm{Na}_{2} \mathrm{CO}_{3}$ washed. IOF. In addition to these solvent changes, several frequency change $\bar{s}$ were made. Due to the mechanical failure of the feed centrifuge, the last 12 hours of HAF was uncentrifuged. All processing in the HA Column was done at $14 \mathrm{~T} / \mathrm{D}$ (Plant equivalent) at 1.07 in. extraction section amplitude. The HA-BC Column operation was stable for the entlre run.

The IA Column was operated at $14 \mathrm{~T} / \mathrm{D}$ plant equivalent rates and a number of different frequencies as well as two different amplitudes in an attempt to achleve the optimum pulsing conditions. For the first 34 hours of operation, the extraction section amplitude was $1.2-i n c h$. This was decreased to 1.07-inch amplitude for the last 6 hours of operation. The principal operating condition changes are indicated on Figure 5.2. The column flooded at a frequency of 68 and extraction section amplitude of 1.2-inch approximately six hours after column startup. The flooding was cyclic in nature and persisted for four hours but was alleviated by increasing the interface control sensitivity. The column flooded again several hours after the frequency was increased from 68 to 72 . Successive reductions in frequency from 72 to 66 to 62 produced stable operation. The column flooded for the third time immediately after the amplitude was decreased to 1.07 -inch (extraction section) and the frequency increased to 80 . The unstable condition continued for the remainder of the run despite frequency decreases to 66 cycles/min.

In addition to the above changes in operating conditions, two differently treated solvents were used as IAX. For the first 30 hours of operation, CP $\mathrm{Ne}_{2} \mathrm{CO}_{3}$ washed IOF was used and for the last eleven hours a change was made to Technical Grade $\mathrm{Na}_{2} \mathrm{CO}_{3}$ washed IOr.

The IBX, IBS, and IC Columns were operated at $14 \mathrm{~T} / \mathrm{D}$ plant equivalent rates for the entire run. However, since the $2 \mathrm{~A}$ and $2 \mathrm{CB}$ Columns were operated at $10 \mathrm{~T} / \mathrm{D}$ plant equivalent rates, the IBX, IBS, and IC Columns were shut down several 


\section{DECLASSIFIED}

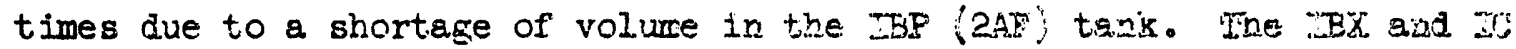
Columns were operated without difficuity exceft for oce to two houre of urstable operation each time these columns were started. The res Column flooded the first few hours after each colum startur. Cecerally the Tss frequency was reduced to $30-32$ cycles per ninute to break the flood. Whe irs colvan was normally operated at a frequency of 50 except for the periods of lower fre quency required to break the floods. See Itigure 5.3.

The 2A-2B Column operation was divided into three fortiors as indicated in Figure 5.4. For the first 28 hours, the $2 A-25$ Coluars were operated st 10 T/D plant equivalent processing rates using Furex Elowsheet - IHW \#3 conditions. During the next 20 hours of operation, $15 \mathrm{mI} / \mathrm{min}$ of $24 \mathrm{IJ}\left(24 \mathrm{si} \approx \mathrm{H}_{2} \mathrm{O}\right.$ 。

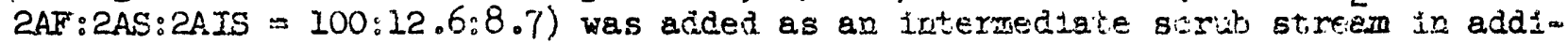
tion to zormal Purex Flowsheet rates. For the last 17 hours of the man, the

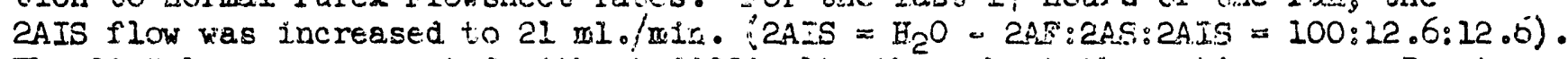
The $2 A$ Colurn was operated without difficulty throughout the entire run. Due to a pertially pluged 2 il valve end or rotameter, the 23 coliun interface position

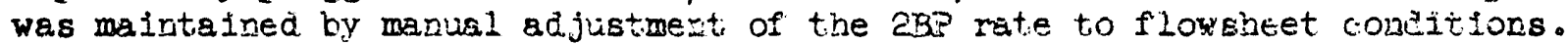

\subsection{Data}

With the exception of the polarograph and the ICF gamm monitor, sil of the in line instrumerts were in working order during the extre rua the privedpel date are flotted in Figures 5.2 to 5.4 . Tables 5.1 t. 5.3 sumertze tibe labor atory analyses.

\subsection{Diecueston}

HAP in line gamo monitor resuits agreed quite weII with laborstory results. The FAP uranium thotometer results, hovever, vere as worch as 20 zo/ i. higher chan the laboratory results, but pert of this differeace rea be attributeble to instrument standardistion yrohiess. After restandgindzatton, the difference between laboratory and inoline results decreased to 245 grams/li ier.

The HAF/AAS in-line decontamiration factors average 2000 during the frech solvent fortion of the run but decreased by a factor of 2.3 when the Hex We.s switched to $\mathrm{CP} \mathrm{Na}_{2} \mathrm{CO}_{3}$ washed IOF. For the remairder of the rury the ineine decontamination factors remained it the rasge of $440-850$ with an average value

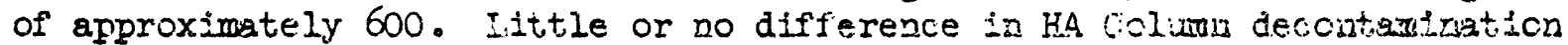
can be attributed to use of uncentrifuged

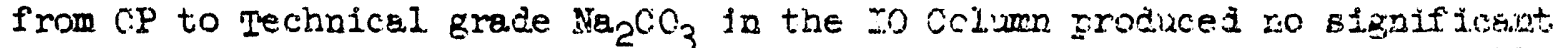

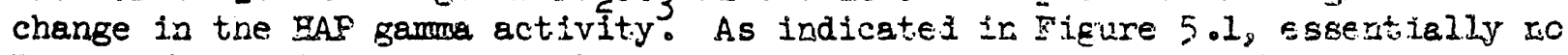
DF was ontained in the HC Colum throughout the entire run. Ine EAP ganma monitor cell was changed twice during the run because of a graduad buildux of background activity on the cell walls. For the six hour period between 0300 and 0900 on 1/19/56, the HAP gama monitor full and entyty cell readings were essentially identical; consequenty no IF values vere ilotted for this perlod. 
The HAW urantum and plutonium losses ranged from a flowsheet value of $<0.2 \%$ to 10-20 times this value. No explanation can be given for these variations. No significant plutonium loss can be attributed to the omission of sodium nitrite from the MAF and the addition of sulfamic acid to the MAF sad BAS, since in general the uranium and plutonium losses were of the same order of magnitude.

Because the IAF in-line gama monitor results were consistently lower than the IAF laboratory gama results, both the in-line and the laboratory decontamination factors relative to IAF were based on the average IAF laboratory total gamma activity $\left(2.91 \times 10^{4} \mathrm{pc} / 1_{0}\right)$. Using this basis, the IAR/IAP In-line and labora. tory decontamination factors check quite well. The IAP uranium photometer results were 5-10 g/l. lower than the laboratory results until the photameter was standardized. After standardization, the photometer and laboratory results agreed within $1 \mathrm{~g} . / \mathrm{l}$. for the reminder of the run. In spite of a number of frequency changes, the IAF/IAP inuline DF renuined in the range of 50-140 during periods of steady operation with an average $\mathrm{DF}$ of approximately 60 . The IAF/IAP DF was essentially the same for both $\mathrm{CP}$ and $\mathrm{T} \in \mathrm{Chnlcal}$ gride $\mathrm{Na}_{2} \mathrm{CO}_{3}$ washed recycled solvent. Because the IA Column flooded during the entire 1.07-in. amplitude period, the effect of amplitude change on IAF/IAF DF cannot be determined. The IAW Pu losses were 7-30 times the Purex Flowsheet - HW \#3 values of $<0.2 \%$, whereas the IAW U losses ranged from $1 / 100$ to $1 / 300$ of the flowsheet value of $<0.2 \%$ during the periods of steady column operation. Since the IAW was not analyzed for $\mathrm{SO}_{4}=$ or $\mathrm{Pu}+3$, these high IAW Pu losses may possibly be attributed to any or all of the following factors:

a) $\mathrm{NaNO}_{2}$ omission from the IAF.

b) Addition of sulfamic acid to the IAF and IAS.

c) Excessive storage time of IAF prior to processing (IAF was stored up to 100 hours).

d) Reduction in $\mathrm{Pu} \mathrm{E}_{\mathrm{a}}^{\mathrm{O}}$ due to sulfate formation.

Despite the fact that both in-line and laboratory IAF/IBU decontamination factors were based on the average laboratory IAF analysis, laboratory factors ranged up to twice the in-line values. Fart of this discrepancy may possibly be attributed to the small difference between full and empty IBU gamma monitor cell readings. Laboratory IBXF, IBU, and ICU total gamma analysis indicate uranium stream decontamination factors of 4-10 across the IB Column with a corresponding value of approximately 1.5 to 3.0 across the IC Column. The overall HAF/ICU laboratory I was $5-6 \times 105$ ( $=5.7-5.8)$. The ICW total gammactivity varied between 12 and $18 \mathrm{pc} / 1$. If it is assumed that this ICW activity is a fixed solvent activity, the decontamination factors would be affected in the following manner:

a) IAF/IAP DF would be approximately 10-30\% higher.

b) IBXF/IBU DF would be higher by a factor of approximately $2-3$.

c) IBU/ICU DF would be essentialiy 1.0 .

\section{DECLASSIFIED}


The IBU plutonium losses ranged from the flowsheet value of $0.2 \%$ to 2 tums flowsheet value. The IBP U losses, however, were as mach as 300 times the flowsheet value of $1 \times 10^{-5 \%}$. The $\mathrm{icW}$ uranium losses were aproximiteiy 10 times the flowsheet value of $<0.2 \%$ throughout the rua.

When the IAF laboratory garma analysis of $2.91 \times 10^{4} \mu \mathrm{c} / 1$. was used as a basis, both the In-IIne and laboratory $I A F / 2 A F$ decontaminat, Lon factors sgreed within $30 \%$. However, the in-1ine 2AF/ $24 P$ decontamination factors were as much as twice the corresponding laboratory values. The $2 A P / 2 B P$ laboratory decontamin. ation factors varled from 7 to 38 , however, for decontsmination factors above 10, the 2RP total gama analyses were at the lower linit of laboratory detection. Consequently, total gamen variations of a factor of two may be stirifuted to unreliablility of laboratory analyses at these low activitiv levels. IIne high 2AF/2RP decontamination factors may be due is part to lack of correction for fixed activity in the solvent. Correction for fixed activity was not made, however, since the $2 B W$ stream was not sarmled. The general effect of this fixed activity correction would be an increased decontamination factor in the $2 A$ Column with a corresponding decreased decontamination factor in the $2 B$ Column. Overall HAF/23P laboratory decontamination factors ranged from $2.1 \times 10^{7}$ to $2.2 \times 10^{8}(\alpha=7.3-8.3)$. Due to initial $2 B$ column plutonium builaup and refluxing of plutonium in the $2 A$ Colum, the $2 B P$ plutonium analyses were considerably lower than flowsheet values. With the exception of the fisirst two $2 B P$ samples ( 3 and 11 hours after column startup), the $2 B$ P gamm/AT retio remained in the range of $1-2 \times 10^{-10} \mathrm{\mu c} /(\mathrm{c} / \mathrm{m})$ wth an average value of $1.2 \times 10^{-10} \mu \mathrm{c} /(\mathrm{c} / \mathrm{m}$ ).

The 2A column operation was divided into three portions in order to study the effect of an intermediate water scrub stream on $U_{1}$ decontamination. Table 5.3 lists the $2 A P$ and $2 A W$ UXI concertrations. Since the $2 A$ J UX I activity

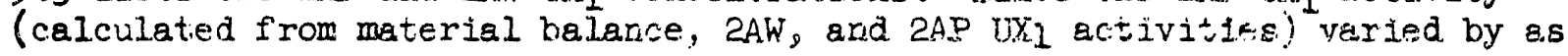
much as a factor of ten during the run, the data obtalned do not warrant any definite conclusions. Some of the discrefancy in 24F UX concentration may possibly be attributed to IBS Colum flooding. In adition to this, the $2 A P$ $\mathrm{UX}_{1}$ concentrations were generally at the lower limit of laboratory detection. The intermediateuscrub $2 \mathrm{~A}$ flowsheet gave excessive $2 \mathrm{AW}$ plutorium losses as ina dicated in Figure 5.4. The $2 A W$ flutonium losses increased from $0.2 .1 .2 \%$ for zero $2 A I S$ flow, to 2.2 Il. o\% for $15 \mathrm{ml} . / \mathrm{min}$. 2AIS flow, to $12.6023 .0 \%$ for 21 $\mathrm{ml} . / \mathrm{min}$. 2AIS $\mathrm{flOw}$. These high product losses were aggravated by the short (8 ft.) Hot Semiworks 2A Column extraction section. A considerabie increase in $2 A$ Colum plutoniun reflux occurred during the latter two portions of the run as indicated by decreasing $2 A \mathrm{~F}$ plutionium concentrations. The 2AW Elintionium losses were based on $2 A F$ plutoniun concentrations. These same losses based on HAF plutonium concentrations would be lower by a factor of two due to the low $2 A F$ plutionium concentration. 
TABLE 5.1

PRECYCLE LABORATORY RESUTIS (1)

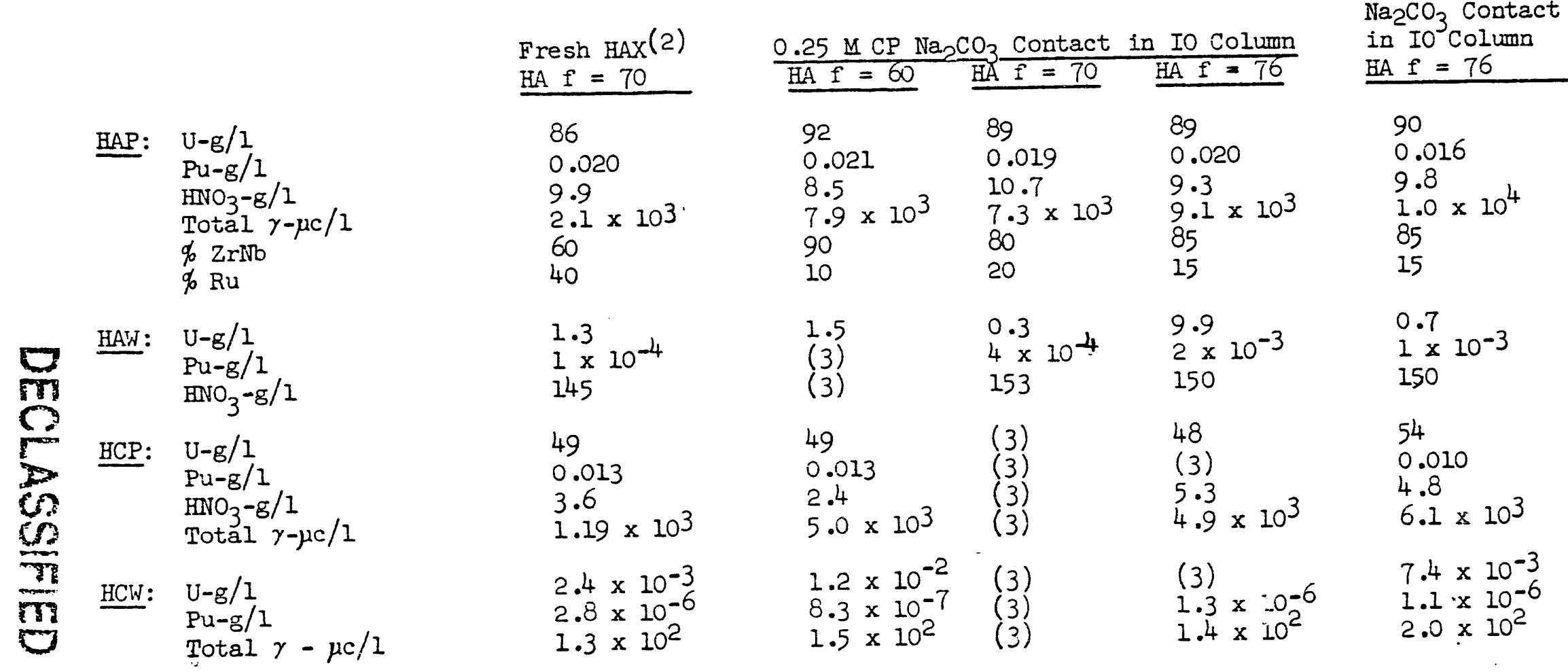

Notes:

(1) HAF composition: $U=332-342 \mathrm{~g} / \mathrm{l} ; \mathrm{Pu}=0.073 \mathrm{~g} / 1 ; \mathrm{HNO}_{3}=130 \mathrm{~g} / 1 ;$ Total $\gamma=2.6 \times 10^{7} \mu \mathrm{c} / 1$.

(2) Batch washed with $0.25 \mathrm{M} \mathrm{CP} \mathrm{Na} \mathrm{CO}_{3}$.

(3) No sample. 


\section{DECLASSIFIED}

\section{TABILE 5.2}

FARTIIION CYCLE IARORA ORY RESULTS (1)

IAP: $\quad U-g / 1$

Fu $-g / 1$

$\mathrm{HNO}_{3}-\mathrm{g} / \mathrm{I}$

Total $\gamma=\mu \mathrm{c} / 1$

of $\mathrm{Z} r \mathrm{NB}$

of $\mathrm{Ru}$

$0.25 \mathrm{M} \mathrm{CP} \mathrm{Nz}_{2} \mathrm{CO}_{3}$

$\frac{\text { Contact in } 10 \text { Column }}{=12 \text { in }}$

$\frac{a=1.2 \frac{1 n}{f}=60-72 \mathrm{f}}{\mathrm{f}=62-66}$

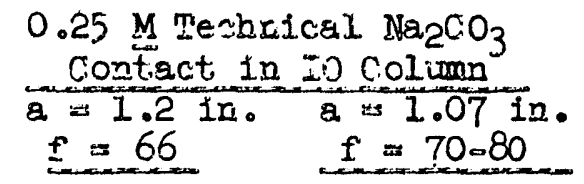

IAW: $\quad U-g / 1$

$\mathrm{Pu}-\mathrm{g} / \mathrm{I}$

$\mathrm{HWO}_{3}-\mathrm{g} / \mathrm{I}$

$\begin{array}{ll}86 & 87 \\ 0.017 & 0.018 \\ 9.5 & 10.0 \\ 74 & 130 \\ 80 & 90 \\ 20 & 10\end{array}$

87

0.020

10.0

103

85

15

89

0.01

11.0

51

85

0.004
0.001
146

0.001

0.003

152

15

$\begin{array}{llll}0.003 & 0.004 & 0.001 & 0.1 \\ 0.001 & 0.001 & 0.003 & 0.005 \\ 116 & 146 & 152 & 163\end{array}$

IBXF: $U-\mathrm{g} / \mathrm{I}$

$\mathrm{Pu}=\mathrm{g} / \mathrm{I}$

$\mathrm{HNO}_{3}-\mathrm{g} / \mathrm{I}$

$75 \quad 77$

0.018

(2)

15

0.019

Total $\gamma-\mu \mathrm{c} / 1$

227

12

205

(2)

$(2)$
$(2)$
$(2)$
$(2)$

IBU: $\quad U-g / 1$

Pu $=g / 1$

Total $\gamma-\mu \mathrm{c} / 1$

76.1

$4 \times 10^{-5} 6 \times 10^{-5}$

(2)

28

of $\mathrm{Zr} \sim \mathrm{s} \mathrm{Tb}$

65

17

$\% \mathrm{Ru}$

35

65

35

(2)

\section{3}

$7 \times 10-5$

34

55

IBP: $U=\mathrm{g} / \mathrm{I}$

$\mathrm{Pu}-\mathrm{g} / \mathrm{I}$

$\mathrm{HNO}_{3}-\mathrm{g} / \mathrm{l}$

0.02

0.16

0.008

0.19

102

Total $\gamma-\mu \mathrm{c} / 1$

1210

95

420

$\begin{array}{ll}(2) & 0.033 \\ (2) & 0.16 \\ (2) & 101 \\ 2) & 870\end{array}$

ICU: $\quad U=\mathrm{g} / \mathrm{l}$

$\mathrm{HNO}_{3}-\mathrm{g} / \mathrm{l}$

Total $\gamma-p c / 1$

$\begin{array}{ll}47 & 48 \\ 7 & 8 \\ 7 & 8\end{array}$

(2)

$\begin{array}{ll}4 & (2) \\ 2\end{array}$

(2)

(2)

ICW: $\quad \mathrm{T}-\mathrm{g} / \mathrm{I}$

$1.2 \quad 2.0$

Total $\gamma-\mu \mathrm{c} / 1$

18

12

(2)

0.9

13

Notes:

(1) IAF Composition: $U=330 \mathrm{~g} / \mathrm{l} ; \mathrm{Pu}=0.077 \mathrm{~g} / \mathrm{l} ; \mathrm{HWO}_{3}=125 \mathrm{~g} / \mathrm{l}$; Total $\gamma=2.9 \times 10^{4} \mu \mathrm{c} / 1 ; \mathrm{Zr} \sim \mathrm{Nb}=85-90 \% ; \mathrm{Ru}=10-15 \%$.

(2) No Sample. 
TARIN 5.3

\section{FINAL PLUTONTUM CYCLE IABORATIORY RESUTIRS (1)}

\begin{tabular}{|c|c|c|c|c|}
\hline & & $0 \mathrm{MI} / \mathrm{Min} 2 \mathrm{AIS}(2)$ & $15 \mathrm{MI} / \mathrm{MIn} 2 \mathrm{AIS}(2)$ & $21 \mathrm{MI} / \mathrm{Min} 2 \mathrm{Ars}(2)$ \\
\hline 2AP: & 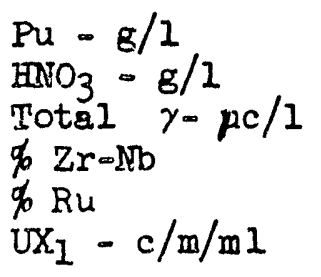 & $\begin{array}{l}0.18 \\
7.0 \\
23 \\
0 \\
>95 \\
30.70\end{array}$ & $\begin{array}{l}0.043 \\
4.4 \\
19 \\
67 \\
33 \\
10-20\end{array}$ & $\begin{array}{l}0.16 \\
7.0 \\
17 \\
0 \\
>95 \\
10.40\end{array}$ \\
\hline 2AW: & $\begin{array}{l}\mathrm{Pu}-\mathrm{g} / \mathrm{l} \\
\mathrm{HrO}_{3}=\mathrm{g} / \mathrm{l} \\
\mathrm{UX}_{1}-\mathrm{c} / \mathrm{m} / \mathrm{ml}\end{array}$ & $\begin{array}{c}(1.24 .9) \times 10^{-4} \\
310 \\
10.120\end{array}$ & $\begin{array}{l}(1.2 .5 .9) \times 10^{-3} \\
270 \\
10.40\end{array}$ & $\begin{array}{l}(7.1 .13 .0) \times 10^{-3} \\
266 \\
30.100\end{array}$ \\
\hline 2BP: & $\begin{array}{l}\text { Pu }-g / 1 \\
\text { Total } \gamma-\mu \mathrm{c} / 1\end{array}$ & $\begin{array}{l}0.04=0.4 \\
1.6=17\end{array}$ & $\begin{array}{l}0.14-0.33 \\
2.2\end{array}$ & $\begin{array}{l}0.28 \\
2.1\end{array}$ \\
\hline
\end{tabular}

Notes:

(1) 2AF Composition: $\mathrm{Pu}=0.06 \mathrm{~g} / 1 ; \mathrm{U}=0.03 \mathrm{~g} / 1 ; \mathrm{EXOO}_{3}=330 \mathrm{~g} / \mathrm{1}$; Total $\gamma=480 \mu \mathrm{c} / 1 ; \mathrm{ZrNb}=95 \% ; \mathrm{Ru}=5 \%$. Calculatea $\mathrm{UX}_{1}=15-150 \mathrm{c} / \mathrm{m} / \mathrm{ml}$.

(2) Purex Flowsheet - HW \#3 $10 \mathrm{I} / \mathrm{D}$ plart equivalent $2 \mathrm{AS}$ flow $=21.6 \mathrm{ml} / \mathrm{min}$. 


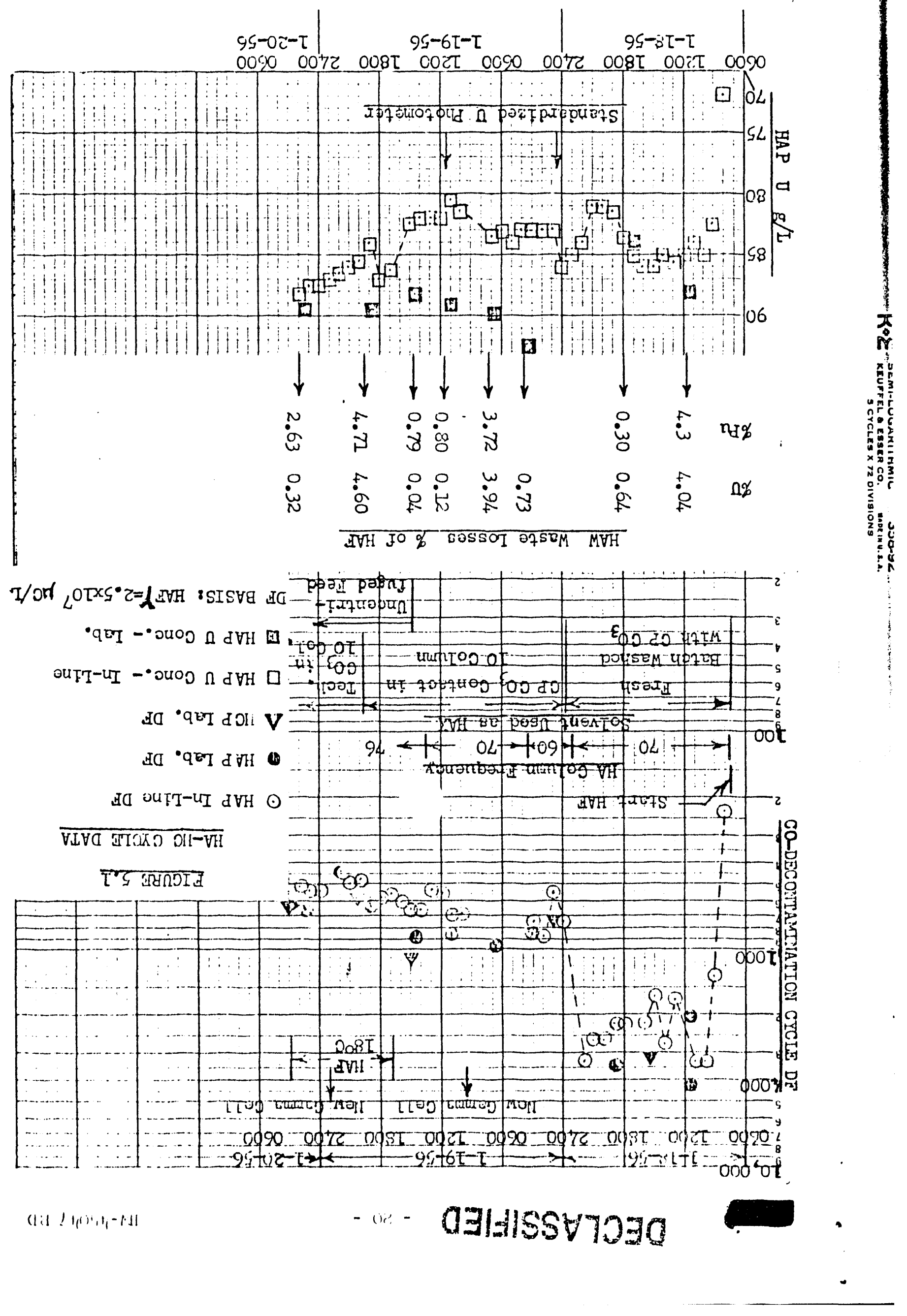




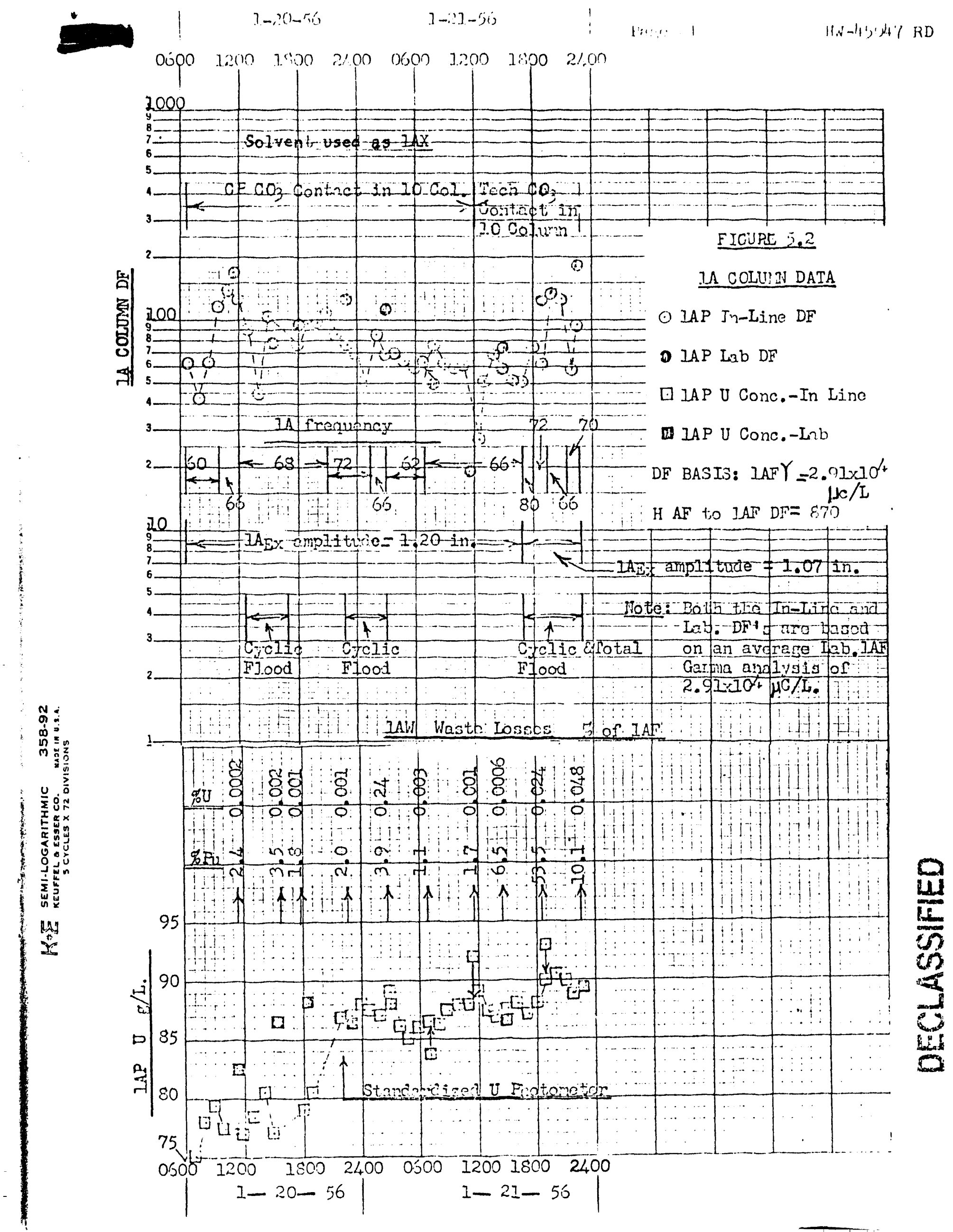




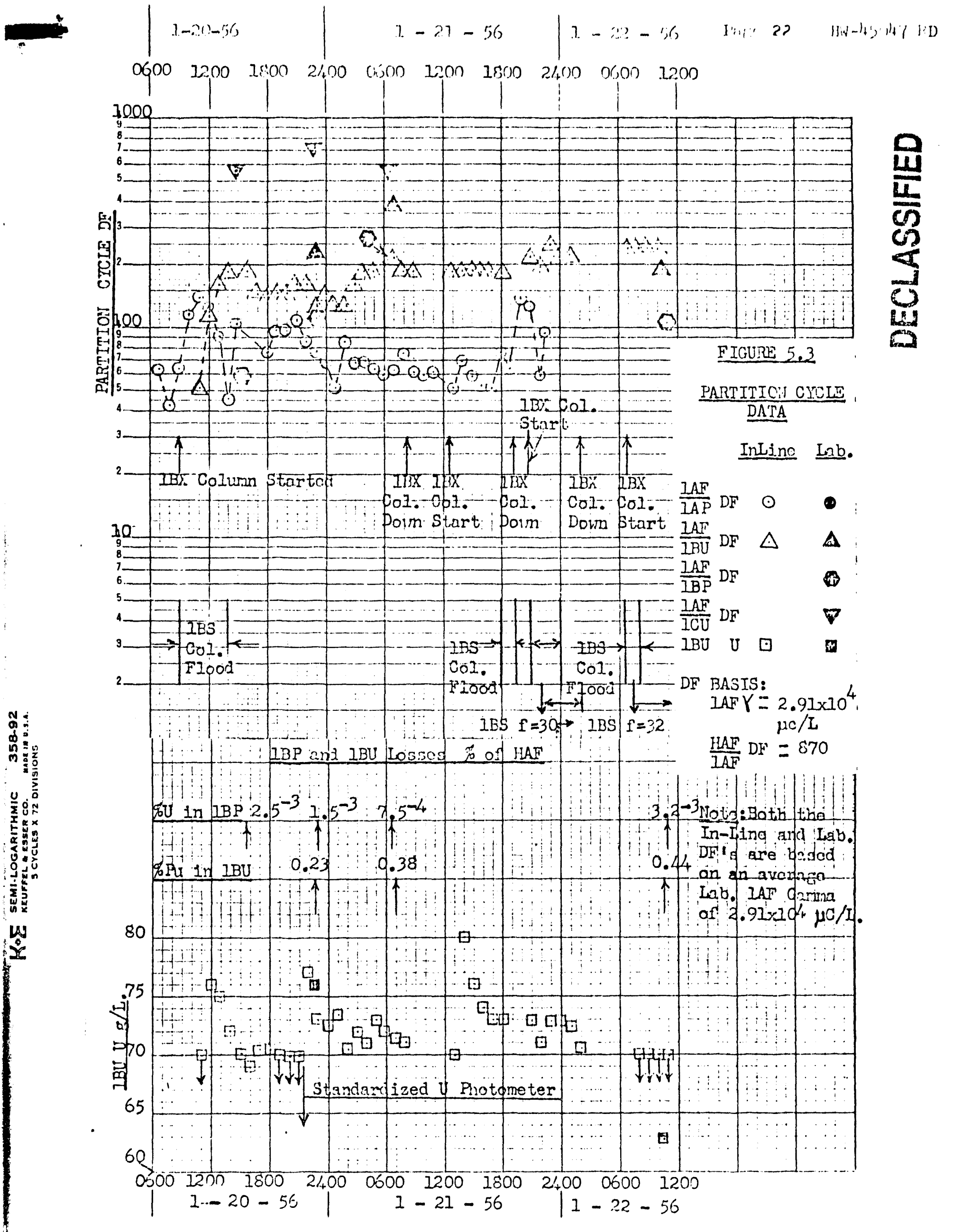



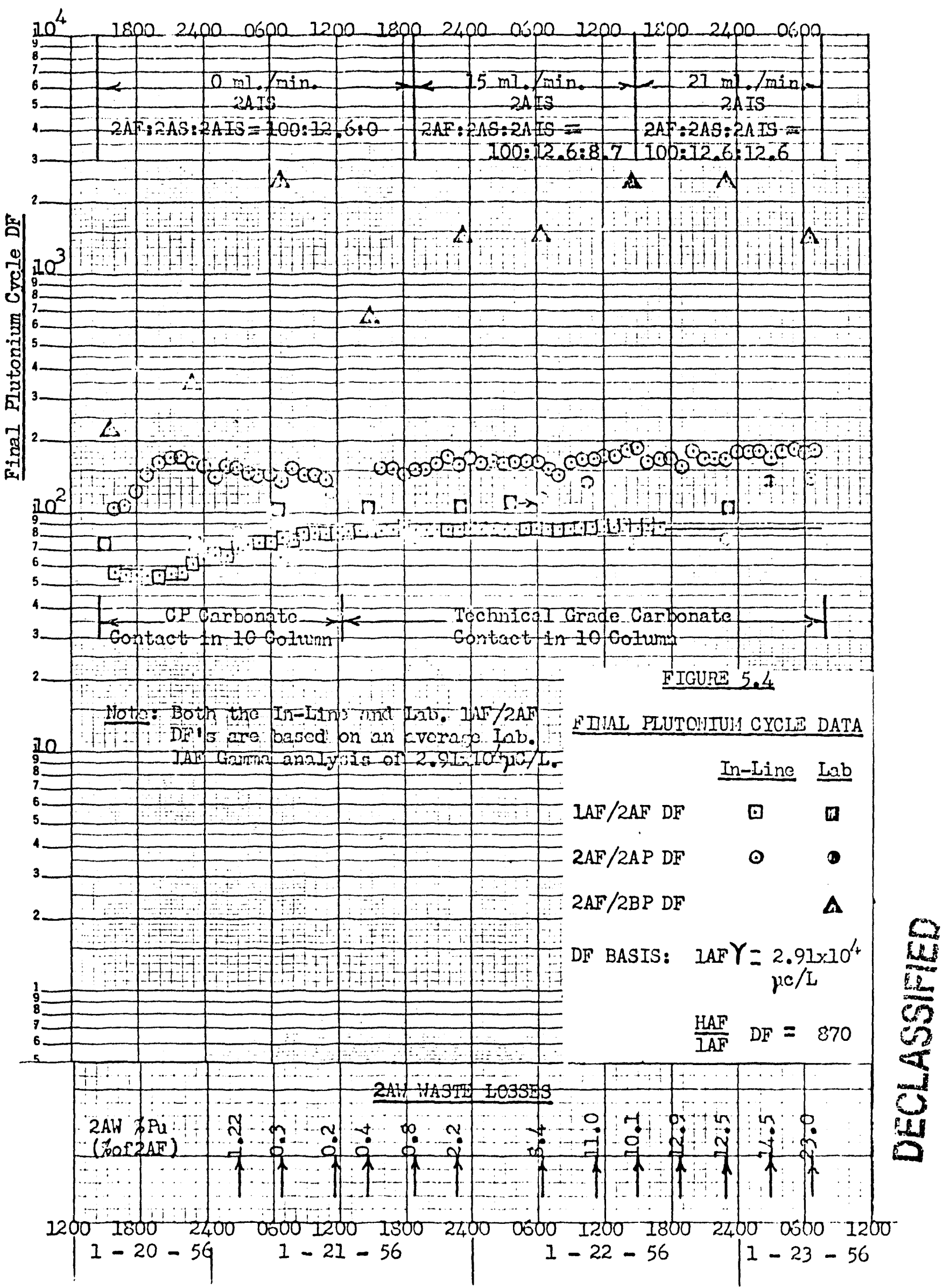


\section{DECLASSIFIED}

$-24=$

$\mathrm{HW}-45047 \mathrm{KD}$

\subsection{SOLVENT RECOVERY}

At the completion of $\mathrm{PX}-12$ all the solvent was jetted out of the system and the solvent tanks and Io Column were given two $5-10 \% \mathrm{BNO}_{3}$ flushes. PX-13 was started with fresh solvent which had been batch washed with $0.25 \mathrm{M} \mathrm{CF} \mathrm{Na}_{2} \mathrm{CO}_{3}$. The Shell E-2342 diluent for this solvent was obtained from the Furex Plant. Fresh solvent was used for the first sixteen hours of HA BC orerstlon. The HCW from this portion of the run was processed through the IO Colimn at $10 \mathrm{~T} / \mathrm{D}$ rates using $0.25 \mathrm{M} C P \mathrm{Na}_{2} \mathrm{CO}_{3}$ as scrub. The Io Column was operated on an intermittent basis during the entire mu at $10 \mathrm{~T} / \mathrm{D}$ rates (plant equivalent). The HAX used for the last 7 hours of $\mathrm{EA}$-HC operation was $0.25 \mathrm{M}$ Technlcal $\mathrm{Na}_{2} \mathrm{CO}_{3}$ washed IOF. The solvent used for the first 30 hours of IA Column operation was $\mathrm{CP} \mathrm{Na}_{2} \mathrm{CO}_{3}$ washed IOF. The solvent used for the last 12 hours of IA Column operation was $0.25 \mathrm{M}$ Technical Grade $\mathrm{Na}_{2} \mathrm{CO}_{3}$ washed IOF. The HCW varied in activity from $130 \mu \mathrm{c} / 1$ to $200 \mu \mathrm{c} / 1$ with $0.004-0.02 \%$ F'u losses and $0.003-0.01 \%$ $U$ losses. The ICW activity varied from $13 \mu \mathrm{c} / 1$ to $18 \mu \mathrm{c} / 1$ with $1-3 \%$ U losses. The Io Column was operated at the following conditions:

$$
\begin{aligned}
& a=0.5-\text { Inch } \\
& f=70 \\
& \text { IOF }: \text { IOS:IOR }=100: 56: 44 \\
& V V=600 \mathrm{gal} / \mathrm{hr} / \mathrm{ft} ?
\end{aligned}
$$

The IOF in-line gama monitor was incperative during the entire run. Inow in-Iine gama readings varied from $120 \mu \mathrm{c} / 1$ to $180 \mu \mathrm{c} / 1$. However, these in-IIne gama monitor results are of doubtful value since the ICW lab gamma analysis were consistentiy lower than the 100 I in-lize gamma readings by a factor of 10 .

\subsection{ACID RECOVERY}

Both of the Waste Concentrators were started with recovered ac:d from $5 X-12$ in the pots. The No. 1 Waste Concentrator vapor line plugged early in the run, thus necessitating shutdown of this concentrator. For the remalnder of the run the HAW was collected in the No. I Waste Concentrator and batch jetted to the service concentrator. For this reason and because of emphasis on other portions of the process, no major effort was de to accumulate acid recovery data during PX-13.

MS: GCo/meb

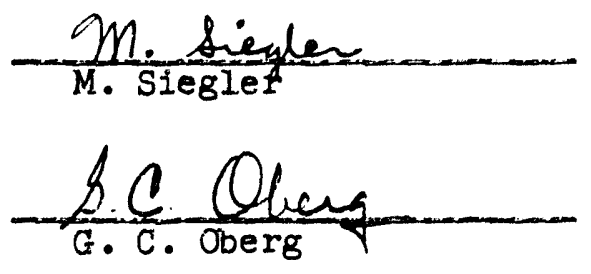


